\title{
Pathogenesis and antigenic characterization of a new East European subtype 3 porcine reproductive and respiratory syndrome virus isolate
}

\author{
Uladzimir U Karniychuk11, Marc Geldhof', Merijn Vanhee', Jan Van Doorsselaere2, Tamara A Saveleva ${ }^{3}$ and \\ Hans J Nauwynck*1
}

\begin{abstract}
Background: Porcine reproductive and respiratory syndrome virus (PRRSV) is divided into a European and North American genotype. East European PRRSV isolates have been found to be of the European genotype, but form different subtypes. In the present study, PRRSV was isolated from a Belarusian farm with reproductive and respiratory failure and designated "Lena". Analyses revealed that Lena is a new East European subtype 3 PRRSV isolate. The main purpose of this investigation was to study the pathogenesis and antigenic characteristics of PRRSV (Lena).

Results: Obvious clinical and virological differences were observed between the animals inoculated with a recent European subtype 1 PRRSV isolate (Belgium A) and animals inoculated with PRRSV (Lena). Three out of six pigs inoculated with PRRSV (Belgium A) had anorexia and low fever at 3, 4 and 5 days post-inoculation (dpi). High fever, anorexia and depression were prominent signs in most pigs inoculated with PRRSV (Lena) between 2 and 28 dpi. Four pigs out of ten died during the experiment. Arcanobacterium pyogenes was isolated from lungs of one animal that died, and Streptococcus suis was isolated from lungs of one animal that was euthanized. The difference in viral titres in sera from PRRSV (Belgium A) and PRRSV (Lena)-infected pigs was statistically significant ( $p<0.05)$ at 7, 10, 14 and $21 \mathrm{dpi}$. The highest viral titres in sera ranged from $10^{4.8}$ to $10^{6.1} \mathrm{TCID}_{50} / \mathrm{ml}$ for PRRSV (Lena) whereas they ranged from $10^{3.1}$ to $10^{4.8}$ $\mathrm{TCID}_{50} / \mathrm{ml}$ for PRRSV (Belgium A).

The replication of PRRSV (Lena) was further studied in depth. Viral titres ranged from $102.5 \mathrm{TCID}_{50} / 100 \mathrm{mg}$ to 105.6 $\mathrm{TCID}_{50} / 100 \mathrm{mg}$ in nasal secretions between 3 and $14 \mathrm{dpi}$ and from $102.8 \mathrm{TCID}_{50} / 100 \mathrm{mg}$ to $10^{4.6} \mathrm{TCID}_{50} / 100 \mathrm{mg}$ in tonsillar scrapings between 3 and $21 \mathrm{dpi}$. High viral titres were detected in lungs (102.3-107.7 $\mathrm{TCID}_{50} / \mathrm{g}$ tissue), tonsils (102.0-106.2 $\mathrm{TCID}_{50} / \mathrm{g}$ tissue) and inguinal lymph nodes (102.2-106.6 $\mathrm{TCID}_{50} / \mathrm{g}$ tissue) until 35,28 and $35 \mathrm{dpi}$, respectively.

To examine the antigenic heterogeneity between the East European subtype 3 isolate Lena, the European subtype 1 strain Lelystad and the North American strain US5, sets of monospecific polyclonal antisera were tested in immunoperoxidase monolayer assays (IPMAs) with homologous and heterologous viral antigens. Heterologous antibody titres were significantly lower than homologous titres ( $p=0.01-0.03$ ) for antisera against PRRSV (Lena) at all sampling time points. For antisera against PRRSV (Lelystad) and PRRSV (US5), heterologous antibody titres were significantly lower than homologous titres at 14 and $21 \mathrm{dpi}(p=0.01-0.03)$ and at 10 and $14 \mathrm{dpi}(p=0.04)$, respectively.
\end{abstract}

Conclusions: Lena is a highly pathogenic East European subtype 3 PRRSV, which differs from European subtype 1 Lelystad and North American US5 strains at both the genetic and antigenic level.

\footnotetext{
* Correspondence: hans.nauwynck@UGent.be

1 Laboratory of Virology, Faculty of Veterinary Medicine, Ghent University, Salisburylaan 133, 9820 Merelbeke, Belgium

Full list of author information is available at the end of the article
}

๑ 2010 Karniychuk et al; licensee BioMed Central Ltd. This is an Open Access article distributed under the terms of the Creative ComBH I I Central mons Attribution License (http://creativecommons.org/licenses/by/2.0), which permits unrestricted use, distribution, and reproduction in any medium, provided the original work is properly cited. 


\section{Background}

Porcine reproductive and respiratory syndrome virus (PRRSV) is a causative agent of reproductive failure in sows and respiratory disorders in pigs and had been firstly recognized in the USA in 1987 [1] and subsequently in Europe in the early 1990s [2]. The PRRSV genome contains nine open reading frames (ORFs) [3]. The ORF1a and ORF1ab code for proteins with apparent replicase and polymerase activities. Four minor structural proteins GP2, E, GP3 and GP4 are encoded by ORF2a, ORF2b, ORF3 and ORF4, respectively [3-5]. The major structural proteins are an envelope glycoprotein (GP5), an unglycosylated membrane protein $(\mathrm{M})$ and a nucleocapsid (N) protein, encoded by ORFs 5,6 and 7, respectively. PRRSV shows a high degree of genetic variation $[6,7]$ and some antigenic heterogeneity [8-10]. Based on genetic and antigenic characteristics, PRRSV is divided into a European and North American genotype [11]. Recently, ORF5 and ORF7 sequences of East European PRRSV isolates were found to be of the European genotype, but group separately from all other European genotype sequences $[12,13]$. Stadejek and colleagues proposed a division of the European genotype into three subtypes: a pan European subtype 1 and East European subtypes 2 and 3 [13]. To our best knowledge, there is no information available concerning the pathogenesis of recent East European PRRSV isolates. Antigenic heterogeneity between European and North American PRRSV strains had been described earlier [8-10], however this issue remains to be determined towards new East European PRRSV subtypes.

The main purpose of the present study was to investigate the pathogenesis and antigenic characteristics of a recently isolated East European subtype 3 PRRSV isolate.

\section{Results}

\section{Sequence information}

The nucleotide sequences of ORF2a, 4, 5, 6 and 7 and deduced aa (amino acid) sequences were determined for the Belarusian PRRSV Lena (GenBank: EU909689, EU909690, EU909691, EU909692, EU909693) and North American PRRSV US5 (except ORF2a) (GenBank: EU926971, EU926972, EU926973, EU926974). All sequences were compared to the European reference strain Lelystad and the North American reference strain VR-2332 (Table 1). Phylogenetic analysis revealed that Lena is a new East European subtype 3 PRRSV isolate. Compared to previously described subtype 3 Belarusian isolates [12,13], PRRSV (Lena) showed between 87-96\% and $90-98 \%$ identity for the GP5 and N proteins, respectively. The Lena GP2, GP4, GP5, M and N proteins were 249, 184, 201, 173 and 124 aa long. PRRSV (Lena) as well as other previously described subtype 3 Belarusian iso- lates had the lowest $\mathrm{N}$ protein size for the European genotype and the largest GP4 protein reported so far.

\section{Clinical findings}

Obvious clinical differences were observed between the animals inoculated with PRRSV (Lena) and the animals inoculated with PRRSV (Belgium A). PRRSV (Lena)inoculated pigs showed a rapid disease evolution. Anorexia and depression were seen in all animals from 5 to $18 \mathrm{dpi}$ and periocular edema was observed from 3 to 9 dpi. Body temperature and respiratory disease scores are summarized in Figure 1. At 2 dpi, seven pigs out of ten had already fever which lasted until 28 dpi ranging from 40 to $42.1^{\circ} \mathrm{C}$. Coughing was observed in some animals from 6 to $24 \mathrm{dpi}$. Four pigs died during the experiment; one at 4 , one at 20 and two at $21 \mathrm{dpi}$. Out of six pigs inoculated with PRRSV (Belgium A), only three animals showed anorexia and fever $\left(40^{\circ} \mathrm{C}\right)$ at 3,4 and $5 \mathrm{dpi}$. Afterwards, temperature returned to normal, animals recovered and stayed healthy and alive until the end of the experiment. Respiratory disorders were not observed in these pigs.

\section{Gross lesions, bacteriology and differential diagnosis}

The results of the postmortem and bacteriological examinations of pigs inoculated with PRRSV (Lena) are presented in Table 2. Arcanobacterium pyogenes was isolated from lungs of one animal that died, and Streptococcus suis was isolated from lungs of one animal that was euthanized. All pigs were negative for porcine circovirus 2, influenza virus, parvovirus and enteroviruses.

\section{Viremia}

Viral titres in sera of PRRSV (Lena)-inoculated animals were first detected at $3 \mathrm{dpi}$ in nine pigs out of 10 . At $7 \mathrm{dpi}$, all pigs had viremia which lasted until $28 \mathrm{dpi}$ (Figure 2). The viral load in sera reached peak levels ranging from $10^{4.0}$ to $10^{6.1} \mathrm{TCID}_{50} / \mathrm{ml}$ at $10 \mathrm{dpi}$ and $10^{4.3}$ to $10^{6.0}$ $\mathrm{TCID}_{50} / \mathrm{ml}$ at $14 \mathrm{dpi}$. A high viremia was observed until 28 dpi. In pigs inoculated with PRRSV (Belgium A), viremia was detected from 3 dpi until $21 \mathrm{dpi}$. At 28 dpi only one pig out of six was still viremic with low viral titre $\left(10^{1.6} \mathrm{TCID}_{50} / \mathrm{ml}\right)$. The viral titres in this group were significantly lower $(\mathrm{p}<0.05)$ than in PRRSV (Lena)-inoculated animals at 7, 10, 14 and $21 \mathrm{dpi}$.

\section{PRRSV titres in different samples}

PRRSV (Lena) was detected in nasal swabs from $3 \mathrm{dpi}$ until $14 \mathrm{dpi}$ and viral titres ranged from $10^{2.5} \mathrm{TCID}_{50} / 100$ $\mathrm{mg}$ to $10^{5.6} \mathrm{TCID}_{50} / 100 \mathrm{mg}$. Tonsillar scrapings collected from all seven animals at $3 \mathrm{dpi}$ had PRRSV titres ranging from $10^{2.8} \mathrm{TCID}_{50} / 100 \mathrm{mg}$ to $10^{4.6} \mathrm{TCID}_{50} / 100 \mathrm{mg}$. At 14 dpi, five samples out of seven were positive with viral 
Table 1: Percentage of the GP2, GP4, GP5, M and N amino acid identity (pairwise comparison)

\begin{tabular}{|c|c|c|c|c|c|c|c|c|c|c|c|c|c|c|c|}
\hline & \multicolumn{3}{|c|}{ GP2 } & \multicolumn{3}{|c|}{ GP4 } & \multicolumn{3}{|c|}{ GP5 } & \multicolumn{3}{|c|}{$M$} & \multicolumn{3}{|c|}{$\mathbf{N}$} \\
\hline & LV & US5 & VR-2332 & LV & US5 & VR-2332 & LV & US5 & VR-2332 & LV & US5 & VR-2332 & LV & US5 & VR-2332 \\
\hline Lena & 92 & NA & 63 & 84 & 71 & 70 & 83 & 55 & 56 & 93 & 79 & 79 & 88 & 61 & 61 \\
\hline LV & 100 & NA & 61 & 100 & 69 & 67 & 100 & 56 & 56 & 100 & 79 & 79 & 100 & 58 & 58 \\
\hline US5 & & 100 & NA & & 100 & 95 & & 100 & 89 & & 100 & 99 & & 100 & 100 \\
\hline
\end{tabular}

LV: Lelystad. NA: Not available.

titres between $10^{2.3} \mathrm{TCID}_{50} / 100 \mathrm{mg}$ and $10^{3.6} \mathrm{TCID}_{50} / 100$ mg. At $21 \mathrm{dpi}$, three tonsillar scrapings out of five were PRRSV positive with viral titres ranging from $10^{2.5}$ $\mathrm{TCID}_{50} / 100 \mathrm{mg}$ to $10^{3.1} \mathrm{TCID}_{50} / 100 \mathrm{mg}$.

The results of virus titration of BAL (bronchoalveolar lavage) fluids and PAMs (porcine alveolar macrophages) are represented in Table 3. High viral titres were already detected in BALs and PAMs at 3 dpi. All BAL fluids and PAM samples were positive until $21 \mathrm{dpi}$. At $28 \mathrm{dpi}$, PAMs from only one pig were positive.

High viral titres were detected in lungs $\left(10^{2.3}-10^{7.7}\right.$ $\mathrm{TCID}_{50} / \mathrm{g}$ tissue), tonsils $\left(10^{2.0}-10^{6.2} \mathrm{TCID}_{50} / \mathrm{g}\right.$ tissue $)$ and inguinal lymph nodes $\left(10^{2.2}-10^{6.6} \mathrm{TCID}_{50} / \mathrm{g}\right.$ tissue) until 35,28 and $35 \mathrm{dpi}$, respectively.

\section{Serology (IPMA results)}

All animals were serologicaly negative prior to inoculation and at 0 and 3 dpi. Six out of nine PRRSV (Lena)inoculated pigs seroconverted at $7 \mathrm{dpi}$ and antibody titres ranged from 1.7 to $4.7 \log 4$. From $10 \mathrm{dpi}$ until the end of experiment all pigs were seropositive with antibody titres ranging from 4.7 to $7.7 \log 4$. In animals inoculated with PRRSV (Belgium A), the course of anti-PRRSV antibody titres did not significantly differ from that in PRRSV (Lena)-inoculated pigs.

\section{Serological cross-reaction (IPMA results)}

All samples collected at 0 and 3 dpi were seronegative regardless of the PRRSV used (Figure 3). Three PRRSV (Lelystad)-inoculated pigs out of ten seroconverted at 7 $\mathrm{dpi}$ and seven more at $10 \mathrm{dpi}$. All seven pigs inoculated with the PRRSV (US5) were seropositive at $7 \mathrm{dpi}$. The overall difference among the homologous antibody titres of the three groups was not significant $(\mathrm{p}=0.1)$. All sera which were negative in the IPMA with homologous antigens were also negative in the IPMA with heterologous antigens. Heterologous antibody titres were significantly lower than homologous titres $(\mathrm{p}=0.01-0.03)$ for antisera against PRRSV (Lena) at all sampling time points. For antisera against PRRSV (Lelystad) and PRRSV (US5), heterologous antibody titres were significantly lower than
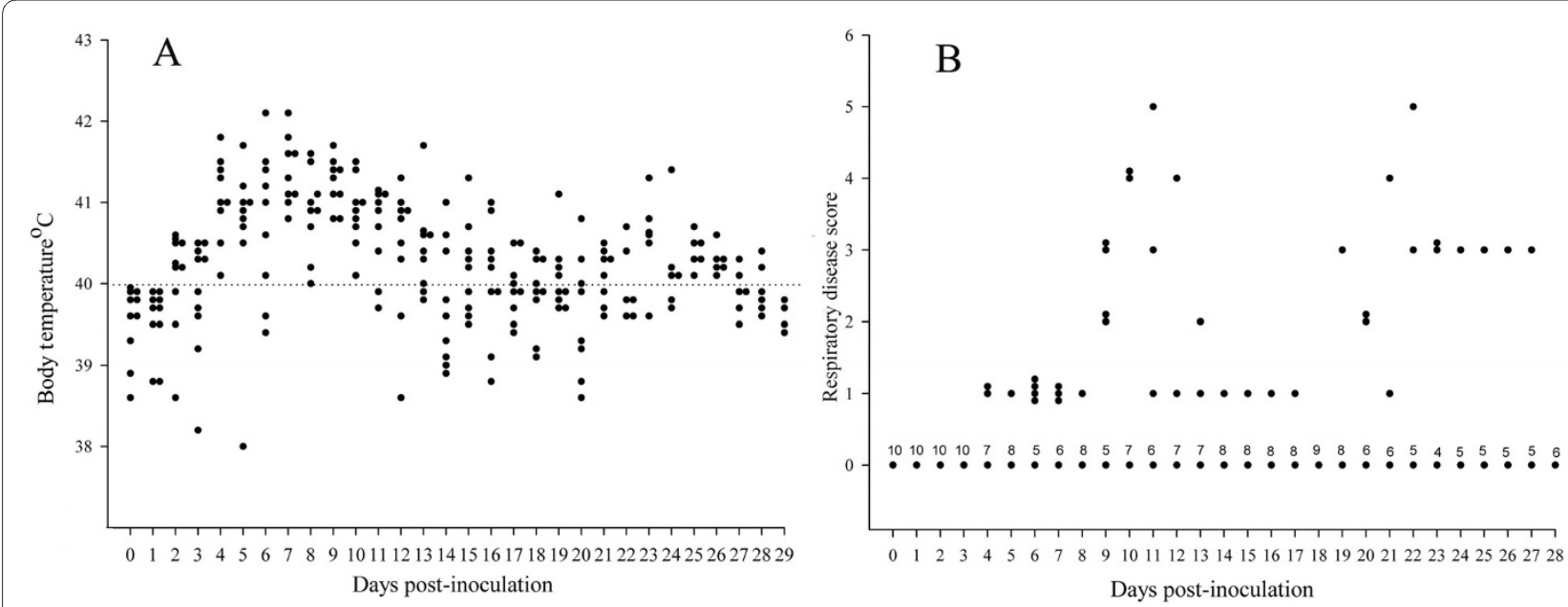

Figure 1 Body temperature and respiratory disease scores in pigs inoculated with PRRSV (Lena). (A) Body temperature of pigs at different time points post-inoculation with PRRSV Lena. Temperature $>40^{\circ} \mathrm{C}$ was considered as fever (dotted line). (B) The respiratory disease scores ranged from 0 to $6: \mathbf{0}=$ normal; $\mathbf{1}=$ mild dyspnea and/or tachypnea when stressed; $\mathbf{2}=$ mild dyspnea and/or tachypnea at rest; $\mathbf{3}=$ moderate dyspnea and/or tachypnea when stressed; $\mathbf{4}$ = moderate dyspnea and/or tachypnea at rest; $\mathbf{5}=$ severe dyspnea and/or tachypnea when stressed; $\mathbf{6}=$ severe dyspnea and/or tachypnea at rest. Stress was induced by holding the pig for $45 \mathrm{sec}$. The numbers above the dots represent the number of animals. 
Table 2: Gross lesions in dead and euthanized pigs inoculated with PRRSV (Lena) and bacterial isolations

\begin{tabular}{|c|c|c|c|}
\hline Pig No & $\begin{array}{l}\text { Diedt/euthanized* } \\
\text { at ... dpi }\end{array}$ & Gross lesions & $\begin{array}{l}\text { Bacterial } \\
\text { isolation }\end{array}$ \\
\hline 1 & $4^{+}$ & No visible gross lesions & - \\
\hline 2 & $20^{+}$ & Fibrinous pleuropneumonia, fibrinous pericarditis & $\begin{array}{l}\text { Arcanobacterium } \\
\text { pyogenes }\end{array}$ \\
\hline 3 & $21^{\dagger}$ & $\begin{array}{l}\text { Fibrinous pleuropneumonia, fibrinous pericarditis, peritonitis, enlarged bronchial lymph } \\
\text { nodes }\end{array}$ & Negative \\
\hline 4 & $21^{\dagger}$ & $\begin{array}{l}\text { Fibrinous pleuropneumonia, fibrinous pericarditis, peritonitis, enlarged bronchial lymph } \\
\text { nodes }\end{array}$ & Negative \\
\hline 5 & $28^{*}$ & $\begin{array}{l}\text { Fibrinous pleuropneumonia, fibrinous pericarditis, peritonitis, enlarged bronchial lymph } \\
\text { nodes }\end{array}$ & $\begin{array}{l}\text { Streptococcus } \\
\text { suis }\end{array}$ \\
\hline 6 & $28^{*}$ & $\begin{array}{l}\text { Fibrinous pleuropneumonia, fibrinous pericarditis, reactive spleen with follicular } \\
\text { hypertrophy of the white pulp }\end{array}$ & Negative \\
\hline 7 & $35^{*}$ & Fibrinous pleuropneumonia, fibrinous pericarditis & Negative \\
\hline 8 & $35^{*}$ & $\begin{array}{l}\text { Fibrinous pleuropneumonia, left diaphragmatic lobe mottled-tan with hemorrhage, } \\
\text { right diaphragmatic lobe mottled-tan with hemorrhage and consolidation, fibrinous } \\
\text { pericarditis, peritonitis }\end{array}$ & Negative \\
\hline 9 & $42^{*}$ & Diaphragmatic lobes with sites of discoloration & - \\
\hline 10 & $42^{*}$ & $\begin{array}{l}\text { Diaphragmatic lobes with sites of discoloration, spleen reactive with follicular } \\
\text { hypertrophy of the white pulp }\end{array}$ & - \\
\hline
\end{tabular}

homologous titres at 14 and $21 \mathrm{dpi}(\mathrm{p}=0.01-0.03)$ and at 10 and $14 \mathrm{dpi}(\mathrm{p}=0.04)$, respectively.

\section{Discussion}

In the present study, PRRSV was isolated from a Belarusian farm with reproductive and respiratory failure. It was designated Lena. The phylogenetic analysis revealed that PRRSV (Lena) is a new East European subtype 3 PRRSV isolate. The main purpose of this investigation was to study the pathogenesis and antigenic characteristics of PRRSV (Lena).

To study the pathogenesis, ten 6-week-old conventional pigs were inoculated with PRRSV (Lena). A fever, lasting for several weeks, and a range of respiratory and systemic clinical signs together with gross lesions such as severe fibrinous pleuropneumonia, pericarditis and peritonitis were observed, with four out of ten animals dying within three weeks post-inoculation. The clinical and pathological picture and high mortality are similar to what is seen in the field in Belarus (information from local veterinarians). A comparison of the findings obtained with PRRSV (Lena) with those obtained with other PRRSV strains revealed similarities with some highly pathogenic American strains [14]. Fever, prolonged viremia and co-infection with bacterial pathogens are prominent findings common to all of them. In this study, the viremia lasted for 4 weeks. As previously described for other PRRSV strains [15], antibodies produced early in infection were not effective in virus clearance. A good correlation was found between the extent of viremia and viral titres in nasal and tonsillar secretions and tissues.

The highest PRRSV (Lena) titres in sera in our investigation ranged from $10^{4.8}$ to $10^{6.1} \mathrm{TCID}_{50} / \mathrm{ml}$ at different dpi. In the present study (European subtype 1 PRRSV isolate Belgium A) and in most previous studies, the highest PRRSV titres ranged from $10^{3.6}$ to $10^{4.8} \mathrm{TCID}_{50} / \mathrm{ml}$. To our knowledge, only few PRRSV strains had been reported to 


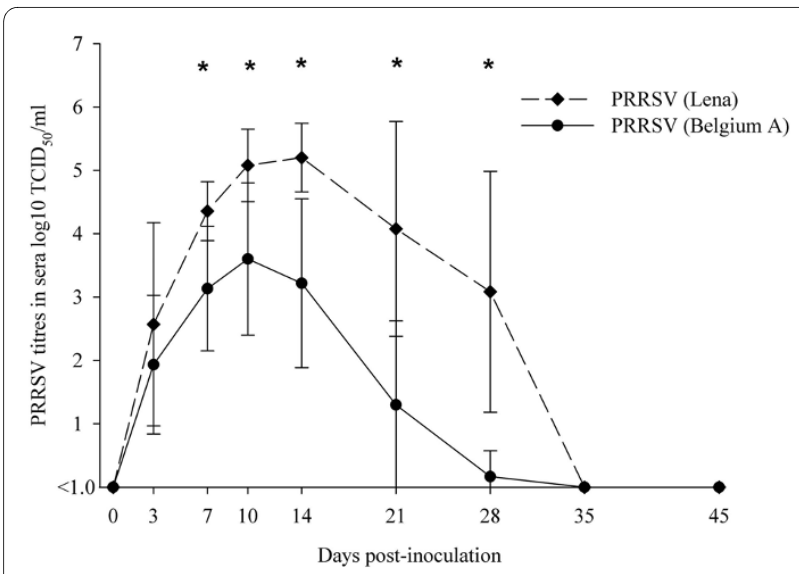

Figure 2 Virus titres in sera of pigs at different days post-inoculation with PRRSV (Lena) and PRRSV (Belgium A). Symbols represent mean titres, whiskers above and below are standard deviations. Titres lower than $10^{1.0} \mathrm{TCID}_{50} / \mathrm{ml}$ were considered to be negative. ${ }^{*}$ The difference is significant between virus titres.

cause abnormally high viremia $\left(10^{5.2}-10^{6.0} \mathrm{TCID}_{50} / \mathrm{ml}\right)$ [16-19]. However, the animals used in those studies were younger (15-35 days of age) than in present experiment and in most studies only a small number of pigs had high PRRSV titres. Two younger pigs (four weeks of age) which were inoculated with PRRSV (Lena) had also higher viral titres in sera, $10^{5.8}$ and $10^{7.8} \mathrm{TCID}_{50} / \mathrm{ml}$ (data not shown).

The severity of the observed clinical signs is most probably not due to a single direct effect of PRRSV (Lena). Secondary infections with other pathogens will have played an important role in the exacerbation of clinical signs. Indeed, in the present study Arcanobacterium pyogenes and Streptococcus suis were isolated from lungs of two pigs. It seems that PRRSV (Lena) infection paves the way for other pathogens. Co-infections of certain PRRSV strains with Arcanobacterium pyogenes as well as Streptococcus suis had been shown to increase the severity of the disease in pigs $[14,20]$. Damaging local respiratory macrophages potentially negatively affects the immune defense and allows bacteria to grow and to cause pathology and disease [21]. Pulmonary intravascular macrophages (PIMs) are thought to be very important in the clearance of circulating blood-borne bacteria in pigs [22]. The detrimental effects of PRRSV on PIMs have been demonstrated before and are considered as factors for the increased susceptibility to secondary infections [23-26]. The severity of disease caused by PRRSV (Lena) as a single agent should be verified in gnotobiotics.

The appearance of new highly virulent PRRSV strains and absence of effective diagnostic procedures and vaccines create a favorable environment for the emergence of devastating outbreaks. Pivotal examples are the recent atypical PRRSV outbreaks in China and Vietnam [27]. Sensitive and specific serological tests are important tools to control PRRSV. To characterize the antigenic heterogeneity between East European subtype 3 Lena, European subtype 1 Lelystad and North American US5 strains, sets of antisera were tested in IPMAs with homologous or heterologous viruses as antigens. Although the three sets of antisera reacted with all strains, the homologous antibody titres were always higher than the heterologous ones. The antigenic difference between the reference European strain Lelystad and Lena was similar to that between Lelystad and US5. Thus, East European subtype 3 Lena, European subtype 1 Lelystad and North American US5 PRRSV strains do share common antigenic determinants that induce production of antibodies reac-

Table 3: Viral titres in BAL fluids and PAMs of pigs at different days post-inoculation with PRRSV (Lena)

\begin{tabular}{|c|c|c|c|c|c|c|c|c|c|c|c|c|}
\hline \multirow[t]{2}{*}{ Pig No } & \multicolumn{6}{|c|}{ PRRSV titres in BAL fluids $(\log 10 \mathrm{TCID50} / \mathrm{ml})$ at ... dpi } & \multicolumn{6}{|c|}{ PRRSV titres in PAMs (log10 TCID50/106 cells) at ... dpi } \\
\hline & 3 & 14 & 21 & 28 & 35 & 42 & 3 & 14 & 21 & 28 & 35 & 42 \\
\hline 2 & 3.6 & 5.3 & & & & & 3.2 & 3.6 & & & & \\
\hline 3 & 3.5 & 5.8 & 2.6 & & & & 4.2 & 2.7 & 4.0 & & & \\
\hline 4 & 4.3 & 3.8 & ND & & & & 4.2 & 2.8 & ND & & & \\
\hline 5 & 5.1 & 6.8 & 7.8 & $<1.0^{*}$ & & & 4.2 & 3.0 & 4.3 & $<1.5^{*}$ & & \\
\hline 6 & ND & ND & ND & $<1.0^{*}$ & & & ND & ND & ND & $2.7^{*}$ & & \\
\hline 7 & 4.8 & 1.5 & 2.5 & & $<1.0^{*}$ & & 4.2 & 2.0 & 1.5 & & $<1.5^{*}$ & \\
\hline 8 & 4.8 & 5.6 & 3.0 & & $<1.0^{*}$ & & 4.2 & 2.7 & 1.8 & & $<1.5^{*}$ & \\
\hline 9 & 3.8 & 1.5 & 3.3 & & & $<1.0^{*}$ & 3.6 & 3.6 & 2.4 & & & $<1.5^{*}$ \\
\hline 10 & ND & ND & ND & & & $<1.0^{*}$ & ND & ND & ND & & & $<1.5^{*}$ \\
\hline
\end{tabular}

Pig 2 died at 20 dpi, pigs 3 and 4 at 21 dpi. *: Day of euthanasia. ND: not done. 

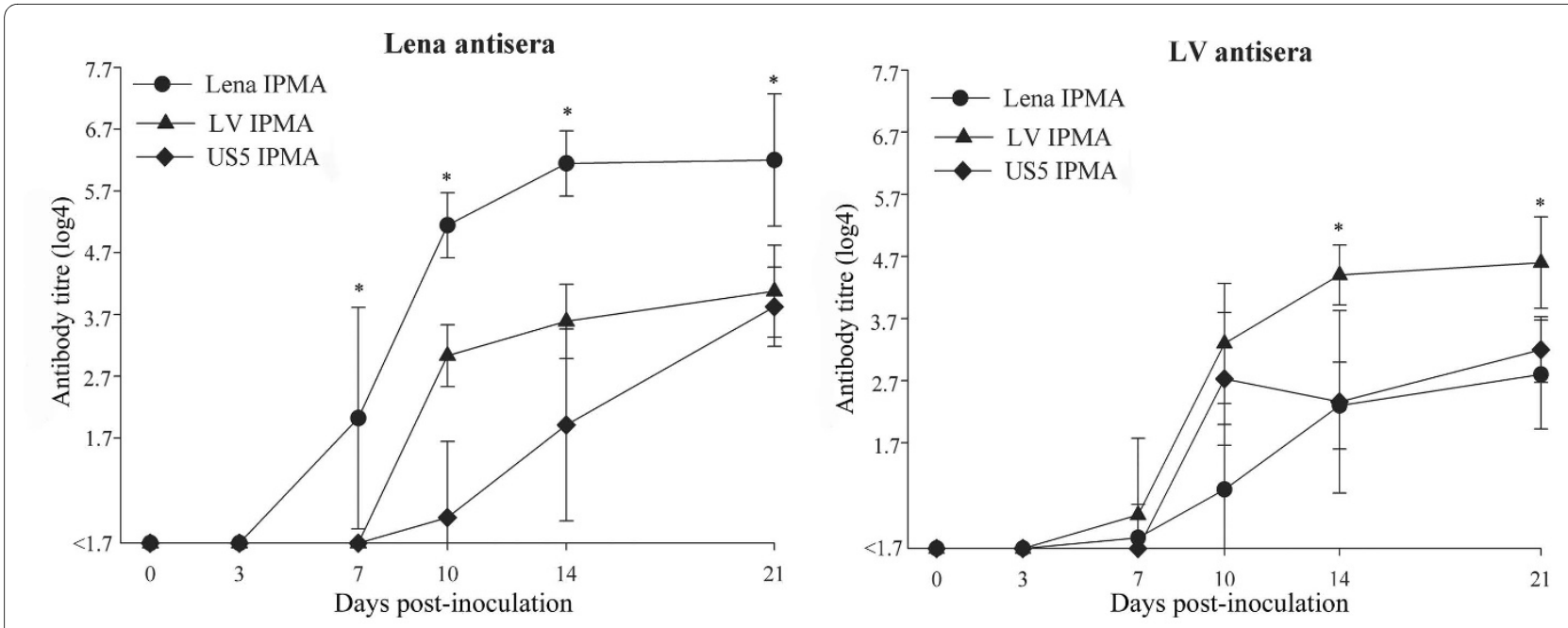

US5 antisera

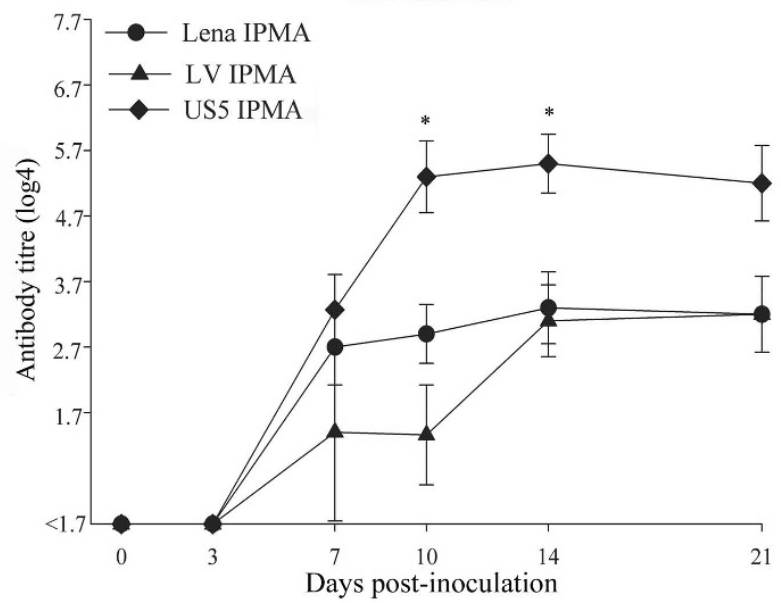

Figure 3 The cross-reaction of antisera with homologous and heterologous IPMA antigens. Symbols represent mean titres, whiskers above and below are standard deviations. Titres lower than $1.7 \log 4$ were considered to be negative. ${ }^{*}$ The difference is significant between homologous and heterologous antibody titres.

tive with the heterologous strains, but there are clear antigenic differences.

Since all present commercial kits for serological diagnosis are based on antigens belonging to European subtype 1 and North American PRRSV, it can be assumed that the observed heterogeneity might affect the accuracy of serological assays in geographical regions where East European Subtype 3 PRRSV strains circulate. Therefore, it is of major importance to validate the sensitivity of the current methods for serological PRRSV diagnosis in these regions.

\section{Conclusions}

Lena is a highly pathogenic East European subtype 3 PRRSV, which differs from European subtype 1 Lelystad and North American US5 strains at both the genetic and antigenic level.

\section{Methods}

\section{Virus isolation}

Samples were collected from a nucleus herd of 5000 sows from the Eastern part of Belarus in January 2007. The herd experienced the following problems: abortion, birth of mummified, dead and weak piglets, high mortality rate before weaning, respiratory disorders and mortality (up to $70 \%$ ) in growing pigs. The herd had been confirmed to be PRRSV positive. Also bacterial pathogens (Streptococcus suis, Escherichia coli) were regularly found in pigs with respiratory disorders. The lungs from weak-born piglets were collected for virus isolation. PAMs were obtained as previously described [28] from 4- to 6-weekold conventional Belgian Landrace pigs from a PRRSVnegative herd. PAMs were cultivated in RPMI 1640 modified medium (Gibco Invitrogen) supplemented with $10 \%$ fetal bovine serum (FBS), $2 \mathrm{mM}$ l-glutamine (BDH 
Table 4: Primers used for amplification and sequencing of PRRSV (Lena) and PRRSV (US5)

\begin{tabular}{|c|c|c|c|c|c|c|c|}
\hline Target & Sequence & Location* & Direction & Target & Sequence & Location* & Direction \\
\hline Lena & & & & US5 & & & \\
\hline \multirow[t]{2}{*}{ ORF2a } & 5'-gtsacaccktatgattacg-3' & $11471-11489$ & Forward & & & & \\
\hline & 5'-tcatrccctattytgcacca-3' & $12642-12623$ & Reverse & & & & \\
\hline \multirow[t]{2}{*}{ ORF4 } & 5'-cggcccaittccatccigag-3' & $12756-12775$ & Forward & ORF4 & 5'-cggcccaittccatccigag-3' & $12756-12775$ & Forward \\
\hline & 5'-cattcagctcgcataicgtcaag-3' & 13653-13631 & Reverse & & 5'-cattcagctcgcataicgtcaag-3' & $13653-13631$ & Reverse \\
\hline \multirow[t]{2}{*}{ ORF5 } & 5'-tgcticatttcitgacacc-3' & $13418-13436$ & Forward & ORF5 & 5'-tgcticatttcitgacacc-3' & $13418-13436$ & Forward \\
\hline & 5'-accttaagigcitatatc-3' & $14190-14173$ & Reverse & & 5'-accttaagigcitatatc-3' & $14190-14173$ & Reverse \\
\hline \multirow[t]{2}{*}{ ORF6 } & 5'-atgggaggcctagacgatttt-3' & 14087-14107 & Forward & ORF6 & 5'-taccaacttcattgtggac-3' & $13922-13940$ & Forward \\
\hline & 5'-ccggccatacttgacgaggt-3' & $14605-14586$ & Reverse & & 5'-acccagcaactggcacag-3' & $14690-14673$ & Reverse \\
\hline \multirow[t]{2}{*}{ ORF7 } & 5'-tggcccctgcccaicacg-3' & $14412-14429$ & Forward & ORF7 & 5'-tggcccctgcccaicacg-3' & $14412-14429$ & Forward \\
\hline & 5'-tcgccctaattgaataggtga-3' & $15050-15030$ & Reverse & & 5'-tcgccctaattgaataggtga-3' & $15050-15030$ & Reverse \\
\hline
\end{tabular}

*Locations are derived from Lelystad virus

Chemicals Ltd.), $1 \%$ non-essential amino acids (Gibco Invitrogen), $1 \mathrm{mM}$ sodium pyruvate (Gibco Invitrogen), and a mixture of antibiotics in a humidified $5 \% \mathrm{CO}_{2}$ atmosphere at $37^{\circ} \mathrm{C}$. Subsequently, PAMs were inoculated with $20 \%$ suspensions of the lungs, CPE was observed and cells were fixed for 10 minutes with methanol $(100 \%)$ at $-20^{\circ} \mathrm{C}$. The virus was identified by incubation with PRRSV-specific monoclonal antibodies P3/27 against the nucleocapsid protein [10] as previously described [29]. Then, the Belarusian isolate, designated Lena was grown in gnotobiotic macrophages and used for sequencing and the pathogenesis study. The virus stock was free from bacteria, pseudorabies virus, classical swine fever virus, parvovirus, enteroviruses and circoviruses.

\section{Sequencing and phylogenetic analysis}

RNA was extracted using an RNeasy Protect Mini Kit (QIAGEN), according to the manufacturer's protocol. Total RNA was used as template in reverse transcription PCR with reverse transcriptase and random hexamer primers (Invitrogen) at $60^{\circ} \mathrm{C}$ annealing temperature and the cycling conditions were used as described by the manufacturer. PCR products were treated with Exonuclease I and Antarctic Phosphatase (New England Biolabs) and used directly for cycle sequencing with a Big Dye Terminator Cycle sequencing Kit V1.1 (Applied Biosystem) and PRRSV primers. Primers were designed based on the alignment of the genome sequences of strains BJ4, MLV, P129, VR2332 and Lelystad (GenBank: AF331831, EF484033, AF494042, EF442771, M96262, respectively). The primers are listed in Table 4 . Cycle sequencing reaction products were purified by ethanol precipitation and separated on an ABI Genetic 310
(Applied Biosystem). In addition, the PCR products were electrophoresed on 5\% agarose gels. PCR fragments of the correct size were cut out of the gel and purified using a QiaQuick gel extraction kit (QIAGEN). The purified fragments were sequenced as described above.

The sequences were analyzed by BlastN and BlastP http://www.ncbi.nlm.nih.gov, and Sixframe, ClustalW and Align http://workbench.sdsc.edu.

\section{Adaptation of the PRRSV (Lena) isolate on MARC-145 cells}

The use of PAMs in an IPMA for the detection of PRRSV antibodies in sera is difficult and expensive since cells have to be harvested from young pigs (preferably specific pathogen free animals). Certain monkey kidney cell lines (MA-104; MARC-145) can be a replacement for macrophages, but such cell lines do not support the growth of all isolates, particularly European ones. In order to get high virus replication in pigs and generate PRRSV (Lena) quasispecies which might favorably contribute to the adaptation on MARC-145 cells, two 4-week-old piglets from a PRRSV-negative farm were inoculated oronasally with $10^{5} \mathrm{TCID}_{50} / \mathrm{pig}$ of macrophage-grown virus. At 9 $\mathrm{dpi}$, the pigs were euthanized and sera, lungs and tonsils were collected. Incubation of MARC-145 cells with suspensions of lungs and tonsils did not give positive results. However, incubation with sera resulted in virus replication which was visible by the presence of CPE (cytopathic effect) and was demonstrated by a PRSV-specific staining. Subsequently, three passages on MARC-145 cells were necessary to further adapt PRRSV (Lena) and a virus stock with a titre of $10^{4.6} \mathrm{TCID}_{50 /} \mathrm{ml}$ was obtained. The alignment of ORF(s) 2a, 4, 5 and 7 of the macrophage-grown and MARC-145 adapted Lena isolates 
revealed a $100 \%$ identity. This virus stock was used for the preparation of IPMA antigens.

\section{Animals and experimental design}

At the age of six weeks, ten conventional pigs from a PRRSV negative herd were inoculated oronasally with $10^{6}$ $\mathrm{TCID}_{50} /$ pig PRRSV (Lena) in $2 \mathrm{ml}$ of phosphate buffered saline (PBS, $1 \mathrm{ml}$ in each nostril). Six pigs from the same origin were inoculated with $10^{6} \mathrm{TCID}_{50} / \mathrm{pig}$ of a recently isolated Belgian PRRSV, designated Belgium A, and served as a reference group for comparison of the clinical picture and virological findings. The Belgian PRRSV had been isolated from lungs and spleen of a stillborn piglet during a PRRSV outbreak in 2007. The herd experienced the following problems: birth of dead and weak piglets, high mortality rate among newborn piglets and respiratory disorders in growing pigs. The herd had been confirmed to be PRRSV positive. Sequencing demonstrated that PRRSV (Belgium A) belongs to the European subtype 1 PRRSV. The animal experiment was approved by the Ethical committee of the Faculty of Veterinary Medicine, Ghent University (EC2008/057).

Clinical signs (body temperature, respiratory disorders, and general signs such as appetite and behaviour) were monitored daily in both groups starting from six days before inoculation until the day of death or euthanasia. Respiratory disorders were scored from 0 to 6 (for interpretation, see legend Figure 1).

From the Lena-inoculated pigs, sera and nasal swabs were collected at $0,3,7,10,14,21,28,35$ and $42 \mathrm{dpi}$ and stored at $-70^{\circ} \mathrm{C}$ for virus titration. Also, sera were stored at $-20^{\circ} \mathrm{C}$ for PRRSV-specific antibody detection. Seven out of ten Lena-inoculated pigs were anesthetized at 3, 14 and $21 \mathrm{dpi}$, for collection of tonsillar scrapings and in vivo pulmonary lavage as previously described [30]. The other three pigs were not treated and served as controls to exclude negative effects of in vivo pulmonary lavage. The lung lavages were centrifuged at $1500 \times \mathrm{g}$ for $10 \mathrm{~min}$. The BAL fluids were collected, PAMs were resuspended in PBS and the total number of PAMs was calculated. Tonsillar scrapings, BAL fluids and PAMs were stored at $70^{\circ} \mathrm{C}$ for titration. At 28,35 and $42 \mathrm{dpi}$, two pigs were euthanized and the following samples were collected: right lungs (apical, cardial and diaphragmatic lobes), tonsils and inguinal lymph nodes. In the case of death, the same organs were sampled. All samples were frozen and stored at $-70^{\circ} \mathrm{C}$ for virus isolation and titration. The PAMs and BAL fluids were collected by pulmonary lavage from the left lung as previously described [31].

From the pigs inoculated with PRRSV (Belgium A), only sera were collected at the same time points as from PRRSV (Lena)-inoculated animals. All samples were stored at $-70^{\circ} \mathrm{C}$ for virus titration and at $-20^{\circ} \mathrm{C}$ for PRRSV antibody detection.

\section{Virus titration, serology and differential diagnosis}

Sera, nasal swabs, tonsillar scrapings, BAL fluids, PAMs and tissue suspensions were titrated on PAMs from PRRSV negative pigs, as previously described [29]. For collection of nasal swabs and tonsillar scrapings, aluminum Rayon sterile plain swabs (COPAN, Italia) were used. Plain swabs were weighed before and after swabbing and viral titres were calculated per $100 \mathrm{mg}$ of secretions. The monoclonal antibody P3/27 against the nucleocapsid protein was used for the detection of PRRSV-infected cells. PRRSV-specific antibodies were detected by an IPMA on Marc-145 cells as previously described [31]. PRRSV (Lena) and PRRSV (Belgium A) adapted on Marc-145 cells were used as IPMA antigens.

In the case of death or euthanasia, pigs were necropsied, lungs and heart were collected and bacteriological analyses were performed. All samples were inoculated on Columbia agar supplemented with 5\% sheep blood (Oxoid, Hampshire, UK) with a Staphylococcus pseudintermedius streak for support of Actinobacillus and Haemophilus spp. growth, and on Columbia CAN agar with 5\% sheep blood (Oxoid, Hampshire, UK). Plates were incubated overnight in a $5 \% \mathrm{CO}_{2}$-inriched environment at $37^{\circ} \mathrm{C}$ and identification of isolated bacteria was performed as previously described [32]. PK-15, MDCK and CK cells were inoculated with $20 \%$ suspensions of lymph nodes and lungs for detection of circovirus 2, influenza virus and parvovirus/enteroviruses, respectively.

\section{Antigenic characterization}

Sera from PRRSV (Lena)-inoculated pigs collected during the pathogenesis study were used. Two other panels of polyclonal antisera were obtained from six-week old pigs inoculated oronasally with $10^{6} \mathrm{TCID}_{50} /$ pig of the PRRSV (Lelystad) [28] (10 pigs) or PRRSV (US5) (7 pigs). Blood samples were collected at $0,3,7,10,14$ and $21 \mathrm{dpi}$. To examine the antigenic heterogeneity between East European subtype 3 Lena, European subtype 1 Lelystad and North American US5 strains, a serological cross-reaction study was undertaken and three panels of antisera were tested in IPMAs with Lena, Lelystad or US5 viruses as antigens.

\section{Statistical analysis}

The difference between the overall courses of antibody titres obtained in three IPMAs with homologous antigens and between virus titres was analyzed by one way ANOVA. The differences between serological results in IPMAs with homologous and heterologous viral antigens at every sampling time point were assessed by non-parametric Wilcoxon matched pairs test. All statistical tests were performed with the STATISTICA 6.0 software. Differences were considered statistically significant at $\mathrm{p} \leq$ 0.05 . 


\section{Authors' contributions}

UUK carried out the isolation of PRRSV (Lena), the pathogenesis study, statistical analyses and antigenic characterization. He drafted the manuscript and participated in the study design, sequencing, phylogenetic analysis and in the adaptation of PRRSV (Lena) on MARC-145 cells. MG carried out the adaptation of PRRSV (Lena) on MARC-145 cells and participated in the pathogenesis study. MV participated in the antigenic characterization study. JVD carried out molecular genetic studies and phylogenetic analyses. TAS participated in the isolation of PRRSV (Lena). HJN conceived the study, coordinated the work and helped in writing the manuscript. All authors read and approved the final manuscript.

\section{Acknowledgements}

The authors acknowledge Oleg P. Ivashkevich, Alexandr O. Sidorenko and Anatoly P. Esmuhanov for their help in the collection of samples from Belarus and Dries Helderweirt, Fernand De Backer, Chantal Vanmaercke, Carine Boone, Lieve Sys for their excellent technical assistance. The research leading to these results has received funding from the European Union Seventh Framework Programme (FP7/2007-2013) under grant agreement n² 245141 (coordinator H. Nauwynck). Uladzimir U. Karniychuk was supported by an INTAS PhD Fellowship (INTAS Ref. Nr 06-1000014-5727).

\section{Author Details}

'Laboratory of Virology, Faculty of Veterinary Medicine, Ghent University, Salisburylaan 133, 9820 Merelbeke, Belgium, 2Department of Health Care and Biotechnology, KATHO Catholic University College of South-West Flanders, Wilgenstraat 32, 8800 Roeselare, Belgium and 3 S.N. Vyshelesskij Institute of Experimental Veterinary Medicine, Briketa 28, 220003, Minsk, Belarus

Received: 18 December 2009 Accepted: 4 June 2010

Published: 4 June 2010

\section{References}

1. Keffaber KK: Reproductive failure of unknown etiology. Am Assoc Swine Pract News/ 1989, 1:1-10

2. White M: Letter to the editor "Blue ear" disease of pigs. Vet Rec 1991 128:574.

3. Snijder EJ, Meulenberg JJM: The molecular biology of arteriviruses. Gen Virol 1998, 79:961-979.

4. Dea S, Gagnon CA, Mardassi H, Pirzadeh B, Rogan D: Current knowledge on the structural proteins of porcine reproductive and respiratory syndrome (PRRS) virus: comparison of the North American and European isolates. Arch Virol 2000, 145:659-688.

5. Meulenberg JJM, Besten DA: Identification and characterization of a sixth structural protein of Lelystad Virus: the glycoprotein GP2 encoded by ORF2 is incorporated in virus particle. Virol 1996, 225:44-51.

6. Andreyev VG, Wesley RD, Mengeling WL, Vorwald AC, Lager KM: Genetic variation and phylogenetic relationships of 22 porcine reproductive and respiratory syndrome virus (PRRSV) field strains based on sequence analysis of open reading frame 5. Arch Virol 1997, 142:993-1001

7. Kapur V, Elam MR, Pawlovich TM, Murtaugh MP: Genetic variation in porcine reproductive and respiratory syndrome virus isolates in the midwestern United States. J Gen Virolo 1996, 77:1271-1276.

8. Frey M, Eernisse K, Landgraf J, Pearson J, Chladek D: Diagnostic testing for SIRS virus at the National Veterinary Service Laboratory (NVSL). Am Assoc Swine 1992, 4:31.

9. Wensvoort G, de Kluyver EP, Luijtze EA, Besten DA, Harris L, Collins JE, Christianson WT, Chladek D: Antigenic comparison of Lelystad virus and swine infertility and respiratory syndrome (SIRS) virus. J Vet Diagn Invest 1992, 4:134-138.

10. Wieczorek-Krohmer M, Weiland F, Conzelmann K, Kohl D, Visser N, Van Woensel $\mathrm{P}$, Thiel HJ, Weiland E: Porcine reproductive and respiratory syndrome virus (PRRSV): monoclonal antibodies detect common epitopes on two viral proteins of European and U.S. isolates. Vet Microbiol 1996, 51:257-266.

11. Mardassi H, Mounir S, Dea S: Identification of major differences in the nucleocapsid protein genes of a Québec strain and European strains of porcine reproductive and respiratory syndrome virus. J Gen Virol 1994, 75:681-685
12. Stadejek T, Oleksiewicz MB, Potapchuk D, Podgorska K: Porcine reproductive and respiratory syndrome virus strains of exceptional diversity in Eastern Europe support the definition of new genetic subtypes. J Gen Virol 2006, 87:1835-1841.

13. Stadejek T, Oleksiewicz MB, Scherbakov AV, Timina AM, Krabbe JS, Chabros K, Potapchuk D: Definition of subtypes in the European genotype of porcine reproductive and respiratory syndrome virus: nucleocapsid characteristics and geographical distribution in Europe. Arch Virol 2008, 153:1479-1488.

14. Johnson W, Roof M, Vaughn E, Christopher-Hennings J, Johnson CR, Murtaugh MP: Pathogenic and humoral immune responses to porcine reproductive and respiratory syndrome virus (PRRSV) are related to viral load in acute infection. Vet Immunol Immunopathol 2004, 102:233-247.

15. Rossow KD, Bautista EM, Goyal SM, Molitor TW, Murtaugh MP, Morrison $\mathrm{RB}$, Benfield DA, Collins JE: Experimental porcine reproductive and respiratory syndrome virus infection in one-, four-, and 10-week-old pigs. J Vet Diagn Invest 1994, 6:3-12.

16. Lopez OJ, Oliveira MF, Alvarez Garcia E, Kwon BJ, Doster A, FA Osorio FA: Protection against porcine reproductive and respiratory syndrome virus (PRRSV) infection through passive transfer of PRRSV-neutralizing antibodies is dose dependent. Clin Vaccine Immunol 2007, 14:269-275.

17. Truong HM, Lu Z, Kutish GF, Galeota J, Osorio FA, Pattnaik AK: A highly pathogenic porcine reproductive and respiratory syndrome virus generated from an infectious CDNA clone retains the in vivo virulence and transmissibility properties of the parental virus. Virology 2004, 325:308-319.

18. Lohsel L, Nielsen J, Eriksen L: Temporary CD8+ T-Cell depletion in pigs does not exacerbate infection with porcine reproductive and respiratory syndrome virus (PRRSV). Viral Immunol 2004, 17:594-603.

19. Martelli P, Cordioli P, Alborali LG, Gozio S, De Angelis E, Ferrari L, Lombardi G, Borghetti P: Protection and immune response in pigs intradermally vaccinated against porcine reproductive and respiratory syndrome (PRRS) and subsequently exposed to a heterologous European (Italian cluster) field strain. Vaccine 2007, 25:3400-3408.

20. Thanawongnuwech R, Brown GB, Halbur PG, Roth JA, Royer RL, Thacker BJ: Pathogenesis of porcine reproductive and respiratory syndrome virusinduced increase in susceptibility to Streptococcus suis infection. Vet Pathol 2000, 37:143-152

21. Galina L, Pijoan C, Sitjar M, Christianson WT, Rossow K, Collins JE: Interaction between Streptococcus suis serotype 2 and porcine reproductive and respiratory syndrome virus in specific pathogen-free piglets. Vet Rec 1994, 134:60-64.

22. Chitko-McKown CG, Blecha F: Pulmonary intravascular macrophages: a review of immune properties and functions. Ann Rech Vet 1992, 23:201-214

23. Thanawongnuwech R, Brown GB, Halbur PG, Roth JA, Royer RL, Thacker BJ: Pathogenesis of porcine reproductive and respiratory syndrome virusinduced increase in susceptibility to Streptococcus suis infection. Vet Pathol 2000, 37:143-152.

24. Thanawongnuwech R, Halbur PG, Ackermann MR, Thacker EL, Royer RL: Effects of low (modified-live virus vaccine) and high (VR-2385)virulence strains of porcine reproductive and respiratory syndrome virus on pulmonary clearance of copper particles in pigs. Vet Pathol 1998, 35:398-406

25. Thanawongnuwech R, Thacker EL, Halbur PG: Effect of porcine reproductive and respiratory syndrome virus (PRRSV) (isolate ATCC VR2385) infection on bactericidal activity of porcine pulmonary intravascular macrophages (PIMs): in vitro comparisons with pulmonary alveolar macrophages (PAMs). Vet Immunol Immunopathol 1997, 59:323-335.

26. Thanawongnuwech R, Thacker EL, Halbur PG: Influence of pig age on virus titer and bactericidal activity of porcine reproductive and respiratory syndrome virus (PRRSV)-infected pulmonary intravascular macrophages (PIMs). Vet Microbiol 1998, 63:177-187.

27. Feng $Y$, Zhao T, Nguyen T, Inui K, Ma Y, Nguyen TH, Nguyen VC, Liu D, Bui QA, To LT, Wang C, Tian K, Gao GF: Porcine respiratory and reproductive syndrome virus variants, Vietnam and China, 2007. Emerg Infect Dis 2008, 14:1774-1776.

28. Wensvoort G, Terpstra C, Pol JMA, ter Laak EA, Bloemraad M, de Kluyver EP, Kragten C, van Buiten L, den Besten A, Wagenaar F, Broekhuijsen JM, Moonen PLJM, Zetstra T, de Boer EA, Tibben HJ, de Jong MF, van 't Veld P, 
Groenland GJR, van Gennep JA, Voets MTh, Verheijden JHM, Braamskamp $\mathrm{J}$ : Mystery swine disease in the Netherlands: the isolation of the Lelystad virus. Vet Q 1991, 13:121-130.

29. Duan X, Nauwynck HJ, Pensaert MB: Virus quantification and identification of cellular targets in the lungs and lymphoid tissues of pigs at different time intervals after inoculation with porcine reproductive and respiratory syndrome virus (PRRSV). Vet Microbiol 1997, 56:9-19.

30. Costers S, Lefebvre DJ, Goddeeris B, Delputte PL, Nauwynck HJ: Functional impairment of PRRSV-specific peripheral CD3+CD8high cells. Vet Res 2009, 40:46.

31. Labarque GG, Nauwynck HJ, Van Reeth K, Pensaert MB: Effect of cellular changes and onset of humoral immunity on the replication of porcine reproductive and respiratory syndrome virus in the lungs of pigs. $J$ Gen Virol 2000, 81:1327-1334

32. Quinn PJ, Carter ME, Markey BK, Carter GR: Clinical Veterinary Microbiology. Mosby, Edinburgh 1994:254-259.

doi: $10.1186 / 1746-6148-6-30$

Cite this article as: Karniychuk et al., Pathogenesis and antigenic characterization of a new East European subtype 3 porcine reproductive and respiratory syndrome virus isolate BMC Veterinary Research 2010, 6:30

Submit your next manuscript to BioMed Central and take full advantage of:

- Convenient online submission

- Thorough peer review

- No space constraints or color figure charges

- Immediate publication on acceptance

- Inclusion in PubMed, CAS, Scopus and Google Scholar

- Research which is freely available for redistribution

Submit your manuscript at www.biomedcentral.com/submit
Ciomed Central 